\title{
THE EFFECT OF MODIFIED ADDITIVES ON STRENGTH AND FROST RESISTANCE IN FIBROUS CONCRETE OF RIGID ROAD PAVEMENTS
}

\author{
${ }^{1}$ Mishutin A.V., Doctor of Engineering, Professor, \\ mishutin52@ukr.net, ORCID 0000-0001-9512-6084 \\ ${ }^{1}$ Chintea L., graduate student, \\ chintea.lucia@gmail.com, ORCID: 0000-0001-7519-4987 \\ ${ }^{1}$ Odessa State Academy of Civil Engineering and Architecture \\ 4, Didrichson street, Odessa, 65029, Ukraine
}

\begin{abstract}
The research is devoted to the development of compositions of modified fiber concrete of rigid road pavements with high strength and frost resistance through the use of metakaolin and a polycarboxylate type superplasticizer.

The compressive strength, tensile strength under bending and frost resistance of concrete and fiber concrete of rigid road pavements were investigated according to the 4-factor optimal plan. In the experiment the amount of concrete components varied: Portland cement, polypropylene fibers, metakaolin, the polycarboxylate type additives Coral ExpertSuid-5.

All mixtures had equal mobility P2 and their W/C depended on the composition of concrete. The use of polypropylene fiber and metakaolin necessitates an increase of W/C to maintain the mobility of the mixture. Increasing the amount of Coral ExpertSuid-5 additive in concrete to 0.9-1\% allows to reduce significantly W/C of the mixture.

Metakaolin as an active mineral additive increases the compressive strength and tensile strength of concrete. Rational in terms of increasing strength is the amount of metakaolin at the level of $20 . .22 \mathrm{~kg} / \mathrm{m}^{3}$. With an increase in the amount of Coral ExpertSuid-5 additive to $0.9 . .1 \%$ due to a decrease of W/C, the compressive strength of concrete increases by $5 . .7 \mathrm{MPa}$, and the tensile strength increases by about $0.5 \mathrm{MPa}$. Due to the introduction of polypropylene fiber, the tensile strength of concrete in bending increases by 0.6..0.9 MPa. But dispersed reinforcement does not affect the compressive strength of concrete. The developed fiber concrete using a rational amount of modifiers, depending on the amount of Portland cement in the composition, has a compressive strength from $55 \mathrm{MPa}$ to $70 \mathrm{MPa}$ and tensile strength from $8 \mathrm{MPa}$ to $9.5 \mathrm{MPa}$. The high strength of fiber-reinforced concretes allows their use in road pavements with the highest load.

Frost resistance of concrete increases by 50 cycles or more when using fiber in an amount of $1.5-2 \mathrm{~kg} / \mathrm{m}^{3}$. Due to the use of a rational amount of modifiers (0.8-1\% Coral ExpertSuid-5 additive and $15-20 \mathrm{~kg} / \mathrm{m}^{3}$ metakaolin), frost resistance of concrete and fiber concrete increases by $50-100$ cycles. The developed modified fiber concretes of rigid road pavements depending on the amount of Portland cement in the composition have frost resistance from F350 to F450, which ensures their sufficient durability.
\end{abstract}

Keywords: strength, frost resistance, road pavement, cement concrete, fiber, metakaolin, superplasticizer.

Introduction. Rigid cement concrete pavements are widely used in the European Union, the United States and other developed countries. These pavements have shown their high performance properties and durability, which confirmed the economic feasibility of their use. In recent years, rigid cement concrete pavements are increasingly used in domestic practice of road construction.

In Ukraine and other countries with temperate climates, frost resistance is one of the main indicators of the quality of concrete pavements, ensuring the durability of materials. Nowadays, one of the most effective materials for cement concrete pavements are modified fiber concretes. These materials are able to provide both high strength and durability of the pavement.

Accordingly, the task of developing modified fiber concrete rigid pavements based on domestic binders, aggregates and modifiers is actual. 
Analysis of recent research and publications. In the conditions of constant influence of transport and weather factors service life of rigid road pavements is two and more times longer in comparison with asphalt concrete pavements [1]. Another important advantage of cement concrete pavements is that bitumen is not used for their production. Oil reserves for bitumen production are more limited than raw material reserves for cement production. It is also important that most of the bitumen in Ukraine is imported [2].

During the manufacture of rigid concrete pavements the achievement of the required level of efficiency simultaneously with high durability and strength of the material is possible only when using modern additives modifiers [3,4]. Today polycarboxylate type superplasticizers are one of the most effective concrete modifiers. For concrete pavements also an effective method of increasing durability is the use of active mineral additives of pozzolanic type [5], in particular metakaolin [6, 7]. Metakaolin significantly affects the process of structure formation of concrete. These changes in the structure increase the durability of concrete by reducing permeability and shrinkage, as well as increasing frost resistance and corrosion resistance [4-7].

Disperse reinforcement is also a known method of improving the mechanical properties of concrete $[4,5,8,9]$. The use of fiber can increase crack resistance, frost resistance, tensile strength and wear resistance of concrete, which is important for paving materials [4, 9]. Accordingly, disperse-reinforced concretes modified with a polycarboxylate-type superplasticizer and an active pozzolanic-type mineral additive are promising materials for rigid pavements that are operated in severe conditions.

Purpose of the work. Development of compositions of modified fiber concretes of rigid pavements with high strength and frost resistance due to the use of metakaolin and polycarboxylate type superplasticizer.

Objects and methods of research. Research of the physical and mechanical properties of concretes and fiber concretes of rigid pavement was carried out according to the optimal 18-point 4factor plan [10]. During the experiment, the following compositional factors varied:

- $\mathrm{X}_{1}$, amount of Portland cement PC II/A-S-500 (CEM II/A-S 42.5), produced by PRJSC "Dyckerhoff Cement Ukraine", from 400 to $500 \mathrm{~kg} / \mathrm{m}^{3}$;

$-X_{2}$, the amount of polypropylene fiber (length $12 \mathrm{~mm}$, diameter $20 \mu \mathrm{m}$ ), from 0 to $2 \mathrm{~kg} / \mathrm{m}^{3}$;

$-X_{3}$, the amount of metakaolin (firing product of enriched kaolin clays), from 0 to $30 \mathrm{~kg} / \mathrm{m}^{3}$;

$-\mathrm{X}_{4}$, the amount of additives of complex action (superplasticizer and curing accelerator) of polycarboxylate type Coral ExpertSuid-5, from 0.6 to $1 \%$ by weight of cement.

Crushed stone of fraction 5-10 mm and quartz sand with a modulus of 2.7 were used as aggregates for fiber concretes.

The compressive strength of concrete was determined according to DSTU B B.2.7-224:2009. The tensile strength in bending was determined on samples of beams measuring $4 \times 4 \times 16 \mathrm{~cm}$. Frost resistance of rigid pavements concretes was determined by the accelerated method in salt water when frozen to $-50^{\circ} \mathrm{C}$.

Research results. The mobility of mixtures of all studied concretes and fiber concretes was equal ( $\mathrm{P} 2$, cone slump from 6 to $8 \mathrm{~cm}$ ), respectively, their W/C depended on the composition. It was found that with an increase in the amount of Portland cement W/C is projected to decrease. The use of polypropylene fiber necessitates an increase of $\mathrm{W} / \mathrm{C}$ to maintain the mobility of the mixture. When using metakaolin due to its additional water consumption, W/C of the mixture also increases. Increasing the amount of Coral ExpertSuid-5 in the concrete composition from $0.6 \%$ to $0.9-1 \%$ significantly reduces the $\mathrm{W} / \mathrm{C}$ of the mixture.

The analysis of this ES-model shows that the amount of polypropylene fiber has a negligible effect on the compressive strength of the studied concretes and fiber concretes. Accordingly, Fig. 1 shows a diagram constructed in (1) in the form of a cube, which reflects the effect of the amount of Portland cement, metakaolin and Coral ExpertSuid-5 on the compressive strength of concretes and fiber concretes. 
Experimental-statistical (ES) model describing the influence of variable composition factors on the compressive strength of the studied concretes and fiber concretes (at standard age) has the form:

$$
\begin{array}{rlr}
\mathrm{f}_{\text {ck.cube }}(\mathrm{MPa})=59.4 & +5.9 \mathrm{x}_{1}-2.4 \mathrm{x}_{1}{ }^{2}+1.1 \mathrm{x}_{1} \mathrm{x}_{2} \pm 0 \mathrm{x}_{1} \mathrm{x}_{3}+1.1 \mathrm{x}_{1} \mathrm{x}_{4} \\
& -2.0 \mathrm{x}_{2}+2.4 \mathrm{x}_{2}{ }^{2} & \pm 0 \mathrm{x}_{2} \mathrm{x}_{3}-1.0 \mathrm{x}_{2} \mathrm{x}_{4} \\
& +1.6 \mathrm{x}_{3}-3.1 \mathrm{x}_{3}{ }^{2} & \\
& +1.5 \mathrm{x}_{4}-1.9 \mathrm{x}_{4} \mathrm{x}_{3} \mathrm{x}_{4}
\end{array}
$$

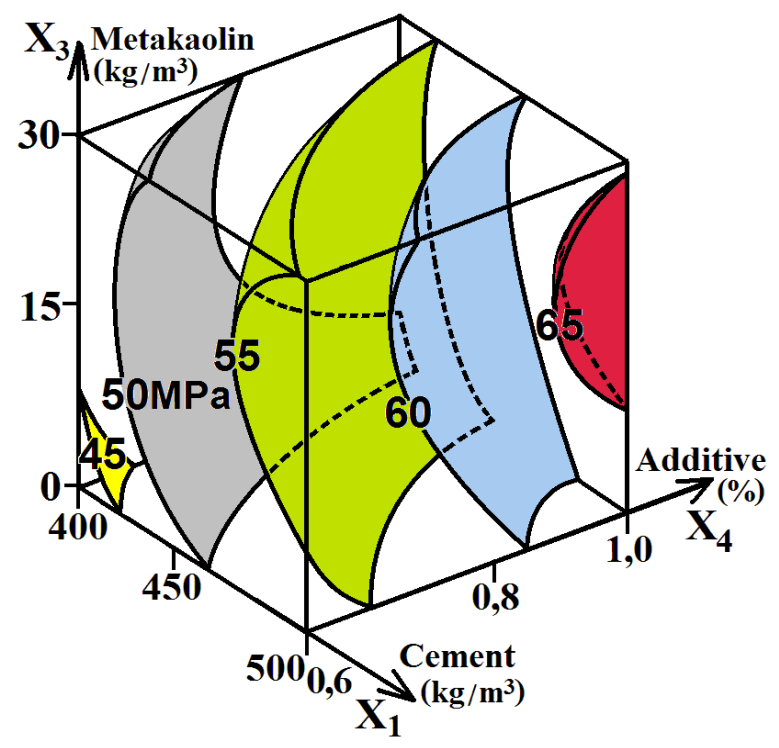

Fig. 1. The effect of the amount of Portland cement, metakaolin and additive Coral ExpertSuid-5 on the compressive strength of concrete and fiber concrete

The analysis of the diagram in Fig. 1 shows that with increasing amount of cement in the composition, the strength of concrete is expected to increase. Metakaolin as an active mineral additive increases the strength of concrete. Rational for the strength of concrete is the amount of metakaolin from 20 to $22 \mathrm{~kg} / \mathrm{m}^{3}$. When increasing the amount of additives of complex action Coral ExpertSuid-5 to $0.9 . .1 \%$, the strength of concrete increases by $5.7 \mathrm{MPa}$. The positive effect of the additive is more noticeable for concretes with metakaolin.

Developed concretes and fiber concretes with a rational amount of modifiers depending on the amount of Portland cement in the composition have a compressive strength of $55 \mathrm{MPa}$ to $70 \mathrm{MPa}$, which corresponds to classes B40-B50. This strength of concrete is even slightly higher than regulated by regulations for cement concrete pavements, which allows to expect greater durability of the pavement. Due to the high early strength, which was found in the previous stages of the research [11], the developed concretes provide the possibility of a faster start of road operation.

For rigid pavements, important quality indicators are not only their compressive strength, but also tensile strength in bending. This is due to the multidirectional loads that the pavement receives during operation. EC-model, which describes the effect of variable compositional factors on tensile strength in bending of the studied concretes and fiber concretes, has the form:

$$
\begin{array}{rlr}
\mathrm{f}_{\mathrm{ctk}}(\mathrm{MPa})=8.30 & +0.61 \mathrm{x}_{1}-0.22 \mathrm{x}_{1}{ }^{2}+0.07 \mathrm{x}_{1} \mathrm{x}_{2} \pm 0 \mathrm{x}_{1} \mathrm{x}_{3}+0.10 \mathrm{x}_{1} \mathrm{x}_{4} \\
& +0.32 \mathrm{x}_{2} \pm 0 \mathrm{x}_{2}^{2} & +0.09 \mathrm{x}_{2} \mathrm{x}_{3}-0.13 \mathrm{x}_{2} \mathrm{x}_{4} \\
& +0.05 \mathrm{x}_{3}-0.17 \mathrm{x}_{3}{ }^{2} & \\
& +0.11 \mathrm{x}_{4}+0.09 \mathrm{x}_{4}{ }^{2} &
\end{array}
$$

According to the EC-model (2) diagrams of the type "squares on squares" are constructed and are shown in Fig. 2. To build the diagram, the square in the $\mathrm{x}_{3}-\mathrm{x}_{4}$ coordinates (the amount of metakaolin and the additive Coral ExpertSuid-5, i.e. the amount of modifiers) was chosen as the bearing square. In the field of the bearing square 9 of constructed squares is reflected the effect of the amount of Portland cement and polypropylene fiber on the tensile strength in bending of concrete and fiber concrete with the appropriate amount of modifiers. 


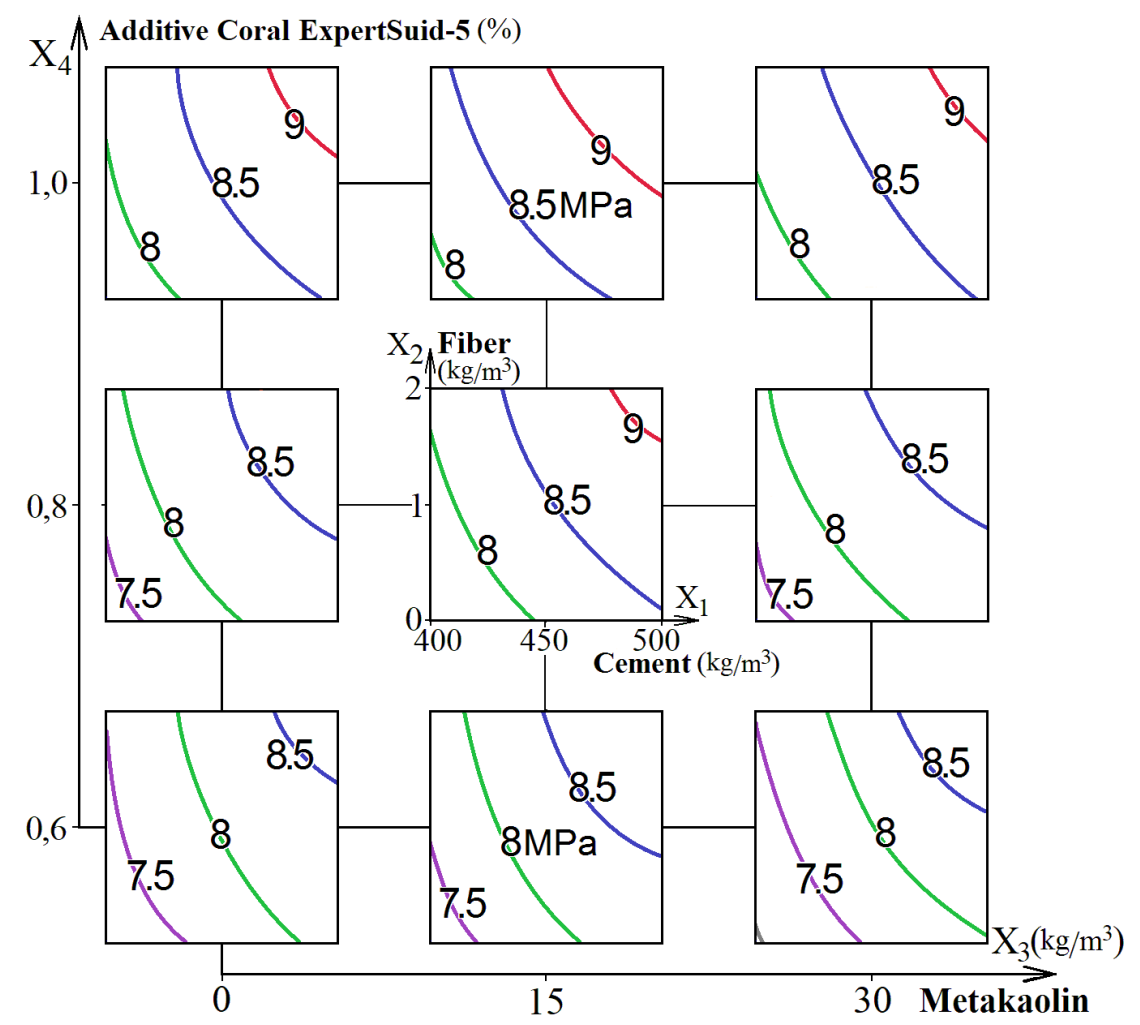

Fig. 2. Influence of varied compositional factors on tensile strength during bending of concretes and fiber concretes

The analysis of the diagram shown in Fig. 2 shows that the tensile strength in bending of concrete and fiber concrete is significantly affected by the amount of Portland cement and the amount of polypropylene fiber. Due to the use of fiber $\mathrm{f}_{\text {ctk }}$ increases by 0.6..0.9 MPa. Thus, disperse reinforcement is an effective method of increasing the stability of cement concrete pavements under tensile loads. The tensile strength in bending of fiber concretes increases by 0.6..0.7 MPa due to the use of a rational amount of modifiers. Overall, modified fiber concrete, depending on the amount of cement in their composition has a level of $\mathrm{f}_{\text {ctk }}$ from 8 to $9.5 \mathrm{MPa}$. Such strength provides high bearing capacity of concretes in rigid pavements of highways.

Concretes of pavements in the course of operation are exposed to repeated influences of freezing and thawing [12]. The number of cycles of freezing and thawing of coatings can be much greater than the number of air temperature transitions through $0^{\circ} \mathrm{C}$. Accordingly, an important condition for ensuring the durability of rigid pavements is their frost resistance. According to the EC model, which is similar to (1) and (2) and which describes the influence of variable composition factors on the frost resistance of concrete and fiber concrete, a diagram of the type «squares on a square» was built (Fig. 3).

The analysis of the diagram shows that the level of frost resistance of the studied concretes and fiber concretes is significantly affected by the amount of Portland cement and the amount of polypropylene fiber. Concretes with a Portland cement amount of $500 \mathrm{~kg} / \mathrm{m}^{3}$ have a frost resistance approximately 100 cycles higher than concretes with a binder amount of $400 \mathrm{~kg} / \mathrm{m}^{3}$.

Frost resistance of concretes of rigid pavements increases by 50 cycles and more at use of fiber in the amount of $1.5-2 \mathrm{~kg} / \mathrm{m}^{3}$. Due to the use of a rational amount of modifiers $(0.8-1 \%$ of the additive Coral ExpertSuid-5 and $15-20 \mathrm{~kg} / \mathrm{m}^{3}$ of metakaolin) frost resistance of concrete and fiber concrete increases by 50-100 cycles depending on the level of other compositional factors. In general, the developed modified fiber concretes of rigid pavements depending on the amount of Portland cement in the composition have frost resistance from F350 to F450, which ensures their sufficient durability. 


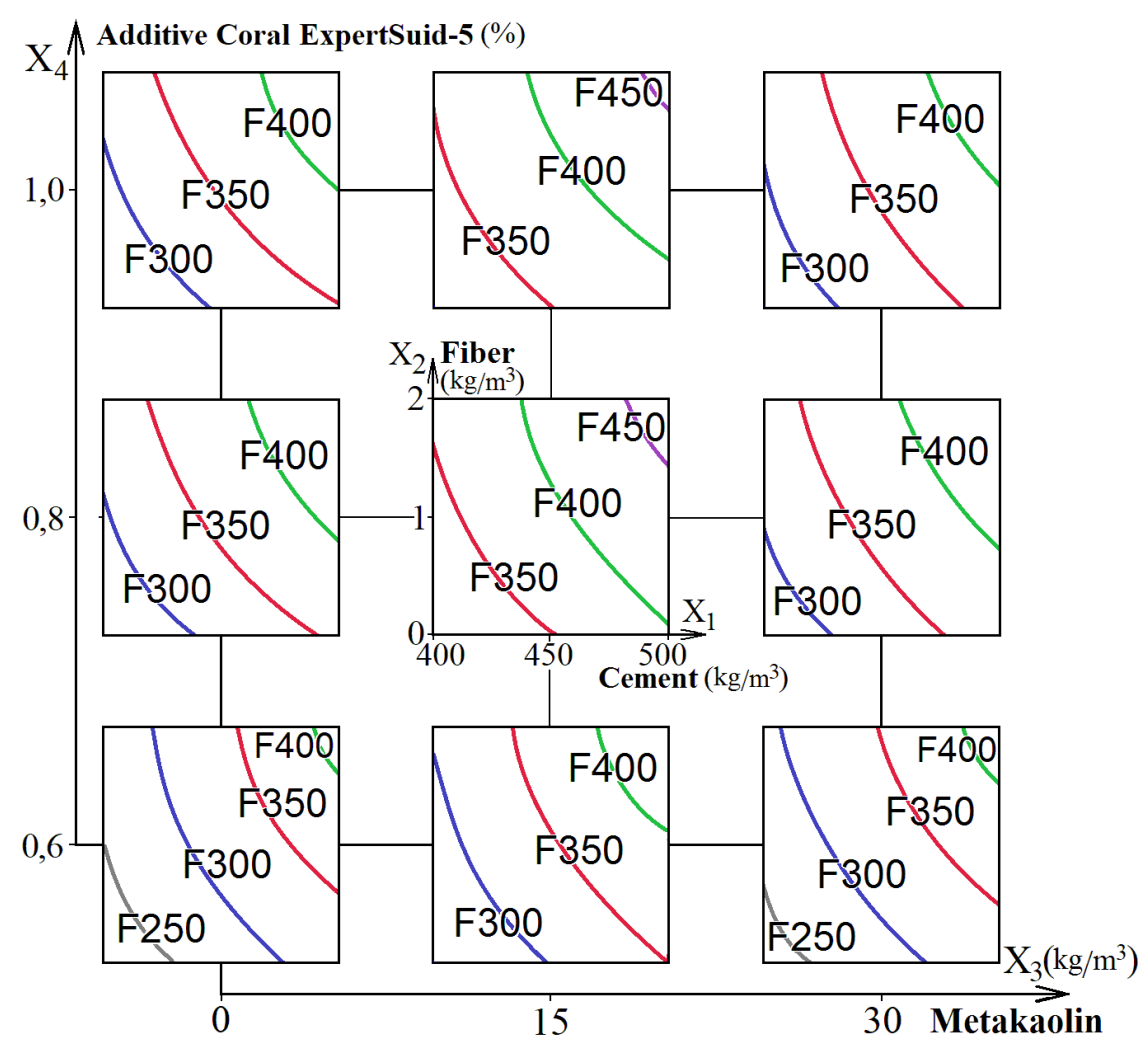

Fig. 3. Influence of varied compositional factors on frost resistance of concretes and fiber concretes

Conclusions and prospects for further researches. Due to the dispersed reinforcement with polypropylene fiber, the use of a rational amount of metakaolin and superplasticizer polycarboxylate type Coral ExpertSuid-5 were obtained fiber concrete rigid pavements with compressive strength up to $70 \mathrm{MPa}$, tensile strength in bending up to $9.5 \mathrm{MPa}$ and frost resistance F450. High strength and frost resistance of modified fiber concretes allow their use in pavements with the highest load and ensure the durability of the material. Further research provides for the analysis of wear resistance of the developed modified fiber concretes as well as their industrial testing.

\section{References}

[1] O.P. Afinogenov, Proektirovanie zhestkih dorozhnyih odezhd. Kemerovo: Kuzbassvuzizdat, 2004.

[2] S.P. Voznyy, "Perspektyvy rozvytku tsementobetonnykh dorih v Ukrayini", Suchasni tekhnolohiyi ta metody rozrakhunkiv u budivnytstvi, no. 6, pp. 47-55, 2017.

[3] Y.M. Sobko, H.Y. Shevchuk, N.I. Topilko, Y.L. Novyts'kyy, "Dorozhni tsementobetony na osnove modyfikovanykh dobavok novoy heneratsiyi", Visnyk natsional'noho universytetu "L'vivs'ka politekhnika". Seriya: Teoriya i praktyka budivnytstva, L'viv: Vydavnytstvo L'vivs'koyi Politekhniky, no. 888, pp. 133-137, 2018.

[4] Y. Chen, GP. Cen, YH. Cui, "Comparative study on the effect of synthetic fiber on the preparation and durability of airport pavement concrete", Construction and Building Materials, vol. 184, pp. 34-44, 2018, https://doi: 10.1016/j.conbuildmat.2018.06.223.

[5] S. Gupta, V.V.L.K. Rao, J. Sengupta, "Evaluation of polyester fiber reinforced concrete for use in cement concrete pavement works", Road materials and pavement design, vol. 9, Issue 3, pp. 441-461, 2008, https://doi: 10.3166/RMPD.9.441-461.

[6] A. Busari, J. Akinmusuru, B. Dahunsi, "Mechanical properties of dehydroxylated kaolinitic clay in self-compacting concrete for pavement construction", Silicon, vol. 11, Issue 5, pp. 2429-2437, 2019, https://doi: 10.1007/s12633-017-9654-6. 
[7] J. Salimi, A.M. Ramezanianpour, M.J. Moradi, "Studying the effect of low reactivity metakaolin on free and restrained shrinkage of high performance concrete", Journal of Building Engineering, vol. 28:101053, 2020, https://doi: 10.1016/j.jobe.2019.101053.

[8] F.N. Rabinovich, Kompozity na osnove dispersno-armirovannykh betonov. Voprosy teorii i proyektirovaniya, tekhnologiya, konstruktsii. M.: ASV, 2004.

[9] H.R. Shen, Y.X. She, P.W. Gao, "The influence of polypropylene fiber on the performance of concrete pavement", Applied Mechanics and Materials, vol. 178-181, pp. 1099-1103, 2012, https://doi: 10.4028/www.scientific.net/amm.178-181.1099.

[10] V.A. Voznesenskiy, T.V. Lyashenko, B.L. Ogarkov, Chislennyye metody resheniya stroitel'no-tekhnologicheskikh zadach na EVM. K.: Vishcha shkola, 1989.

[11] A.V. Mishutina, L. Kintia, "Prochnost' fibrobetonov zhestkikh dorozhnykh pokrytiy v raznom vozraste", Vestnik Odesskoy gosudarstvennoy akademii stroitel'stva i arkhitektury, no. 77, pp. 135-141, 2019, https://doi:10.31650/2415-377X-2019-77-135-141.

[12] A.V. Mishutin, M.V. Zavoloka, L. Kintia, "Management of cement-concrete road pavement structure", Journal of Engineering Science, vol. XXVI, no. 1, pp. 91-95, 2019, https://doi:10.5281/zenodo.2649980.

\title{
ВПЛИВ МОДИФІКОВАНИХ ДОБАВОК НА МІЦНІСТЬ І МОРОЗОСТІЙКІСТЬ ФІБРОБЕТОНІВ ЖОРСТКИХ ДОРОЖНІХ ПОКРИТТІВ
}

\author{
${ }^{1}$ Мішутін А.В., д.т.н., професор, \\ mishutin52@ukr.net, ORCID 0000-0001-9512-6084 \\ ${ }^{1}$ Кінтя Л., аспірант, \\ chintea.lucia@gmail.com, ORCID: 0000-0001-7519-4987 \\ ${ }^{1}$ Одеська державна академія будівництва та архітектури \\ вул. Дідріхсона, 4, м. Одеса, 65029, Україна
}

Анотація. Дослідження присвячені розробці складів модифікованих фібробетонів жорстких дорожніх покриттів 3 високою міцністю i морозостійкістю за рахунок використання метакаоліну і суперпластифікатору полікарбоксилатного типу.

За 4-х факторним оптимальним планом досліджені міцність на стиск, міцність на розтяг при згині і морозостійкість бетонів і фібробетонів жорстких дорожніх покриттів. У експерименті варіювалась кількість таких складових бетону: портландцементу, поліпропіленової фібри, метакаоліну, добавки полікарбоксилатного типу Coral ExpertSuid-5.

Всі суміші мали рівну рухомість Р2 і їх В/Ц залежало від складу бетону. Введення поліпропіленової фібри і метакаоліну викликає необхідність підвищення В/Ц для збереження рухомості суміші. Підвищення у складі бетону кількості добавки Coral ExpertSuid-5 до 0,9-1\% дозволяє відчутно знизити В/Ц суміші.

Метакаолін, як активна мінеральна добавка, сприяє підвищенню міцності бетону на стиск і на розтяг при згині. Раціональною з позицій підвищення міцності є кількість метакаоліну на

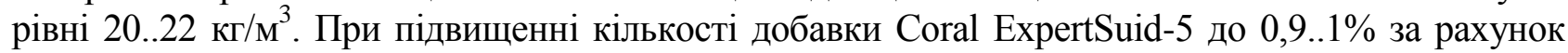
зниження В/Ц міцність бетонів на стиск зростає на $5.7 \mathrm{MПа,} \mathrm{міцність} \mathrm{на} \mathrm{розтяг} \mathrm{при} \mathrm{згині}$ зростає приблизно на 0,5 МПа. За рахунок введення поліпропіленової фібри міцність бетону на розтяг при згині зростає на 0,6..0,9 МПа, при цьому дисперсне армування не впливає на міцність бетону на стиск. Розроблені фібробетони при використанні раціональної кількості модифікаторів в залежності від кількості портландцементу у складі мають міцність на стиск від 55 МПа до 70 МПа і міцність на розтяг при згині від 8 МПа до 9,5 МПа. Висока міцність фібробетонів дозволяє використовувати їх в покриттях доріг з найбільшим навантаженням.

При введенні фібри у кількості 1,5-2 кг/м³ морозостійкість бетонів зростає на 50 циклів і більше. За рахунок використання раціональної кількості модифікаторів (0,8-1\% добавки

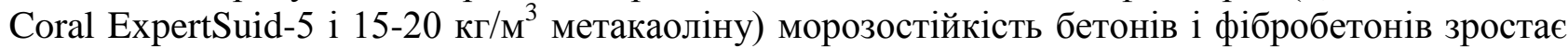
на 50-100 циклів. Розроблені модифіковані фібробетони жорстких дорожніх покриттів в 
залежності від кількості портландцементу у складі мають морозостійкість від F350 до F450, що забезпечує їх достатню довговічність.

Ключові слова: міцність, морозостійкість, дорожнє покриття, цементобетон, фібра, метакаолін, суперпластифікатор.

\title{
ВЛИЯНИЕ МОДИФИЦИРОВАННЫХ ДОБАВОК НА ПРОЧНОСТЬ И МОРОЗОСТОЙКОСТЬ ФИБРОБЕТОНОВ ЖЕСТКИХ ДОРОЖНЫХ ПОКРЫТИЙ
}

\author{
${ }^{1}$ Мишутин А.В., д.т.н., профессор, \\ mishutin52@ukr.net, ORCID 0000-0001-9512-6084 \\ ${ }^{1}$ Кинтя Л., аспирант, \\ chintea.lucia@gmail.com, ORCID: 0000-0001-7519-4987 \\ ${ }^{1}$ Одесская государственная академия строительства и архитектуры \\ ул. Дидрихсона, 4, г. Одесса, 65029, Украина
}

\begin{abstract}
Аннотация. Исследования посвящены разработке составов модифицированных фибробетонов жестких дорожных покрытий с высокой прочностью и морозостойкостью за счет использования метакаолина и суперпластификатора поликарбоксилатного типа.

Согласно 4-х факторному оптимальному плану исследовались прочность на сжатие, прочность на растяжение при изгибе и морозостойкость бетонов и фибробетонов жестких дорожных покрытий. В эксперименте варьировалось количество таких составляющих бетона: портландцемента, полипропиленовой фибры, метакаолина, добавки поликарбоксилатного типа Coral ExpertSuid-5.

Все смеси имели равную подвижность Р2 и их В/Ц зависело от состава бетона. Введение полипропиленовой фибры и метакаолина вызывает необходимость повышения В/Ц для сохранения подвижности смеси. Повышение в составе бетона количества добавки Coral ExpertSuid-5 до 0,9-1\% позволяет ощутимо снизить В/Ц смеси.

Метакаолин, как активная минеральная добавк, способствует повышению прочности бетона на сжатие и на растяжение при изгибе. Рациональной с точки зрения повышения прочности является количество метакаолина на уровне $20 . .22$ кг/ $\mathrm{m}^{3}$. При повышении количества добавки Coral ExpertSuid-5 до 0,9..1\% за счет снижения В/Ц прочность бетонов на сжатие возрастает на 5..7 МПа, прочность на растяжение при изгибе возрастает примерно на 0,5 МПа. За счет введения полипропиленовой фибры прочность бетона на растяжение при изгибе возрастает на 0,6..0,9 МПа, при этом дисперсное армирование не влияет на прочность бетона на сжатие. Разработанные фибробетоны при использовании рационального количества модификаторов в зависимости от количества портландцемента в составе имеют прочность на сжатие от 55 МПа до 70МПа и прочность на растяжение при изгибе от 8 МПа до 9,5 МПа. Высокая прочность фибробетонов позволяет использовать их в покрытиях дорог с наибольшей нагрузкой.

При введении фибры в количестве $1,5-2$ кг/ $\mathrm{m}^{3}$ морозостойкость бетонов возрастает на 50 циклов и более. За счет использования рационального количества модификаторов (0,8-1\% добавки Coral ExpertSuid-5 и 15-20 кг/м³ метакаолина) морозостойкость бетонов и фибробетонов возрастает на 50-100 циклов. Разработанные модифицированные фибробетоны жестких дорожных покрытий в зависимости от количества портландцемента в составе имеют морозостойкость от F350 до F450, что обеспечивает их достаточную долговечность.

Ключевые слова: прочность, морозостойкость, дорожное покрытие, цементобетон, фибра, метакаолин, суперпластификатор.
\end{abstract}

Стаття надійшла до редакції 20.05.2020 